OPEN ACCESS

Edited by:

Guillermo Raul Castro,

Consejo Nacional de Investigaciones

Científicas y Técnicas (CONICET),

Argentina

Reviewed by:

George Kokotos,

National and Kapodistrian University of

Athens, Greece

Luke Hunter,

University of New South Wales,

Australia

*Correspondence:

Rosaria Villano

rosaria.villano@icb.cnr.it

Specialty section:

This article was submitted to

Green and Sustainable Chemistry,

a section of the journal

Frontiers in Chemistry

Received: 20 January 2022

Accepted: 08 February 2022

Published: 01 March 2022

Citation:

Villano R, Tinto F and Di Marzo V (2022) Facile and Sustainable Synthesis of

Commendamide and its Analogues.

Front. Chem. 10:858854.

doi: 10.3389/fchem.2022.858854

\section{Facile and Sustainable Synthesis of Commendamide and its Analogues}

\author{
Rosaria Villano ${ }^{1 *}$, Francesco Tinto $^{2}$ and Vincenzo Di Marzo ${ }^{1,3}$ \\ ${ }^{1}$ Istituto di Chimica Biomolecolare, Pozzuoli, Italy, ${ }^{2}$ Département de Médecine, Faculté de Médecine, Centre de Recherche de \\ I'Institut Universitaire de Cardiologie et de Pneumologie de Québec, Université Laval, Quebec City, QC, Canada, ${ }^{3}$ Canada \\ Excellence Research Chair on the Microbiome-Endocannabinoidome Axis in Metabolic Health, Faculty of Medicine and Faculty of \\ Agricultural and Food Sciences, Centre NUTRISS, Centre de Recherche de l'Institut de Cardiologie et Pneumologie de l'Université \\ et Institut sur la Nutrition et les Aliments Fonctionnels, Université Laval, Quebec City, QC, Canada
}

Commendamide, or $\mathrm{N}$-(3-hydroxypalmitoyl)-glycine $\mathbf{1 a}$, is a gut microbiota-derived bioactive metabolite, structurally similar to long-chain $\mathrm{N}$-acyl-amino acids which belong to the complex lipid signaling system known as endocannabinoidome and play important roles in mammals through activation of, inter alia, G-protein-coupled receptors (GPCRs). In this work, we describe a simple, green and economic method for the preparation of commendamide 1a, a GPCR G2A/132 agonist. The developed protocol is general and could also be applied to the synthesis of deuterated commendamide $\mathbf{1 b}$, as well as to other minor microbiota-derived metabolites, such as the analog 2.

Keywords: commendamide, microbiota, endocannabinoidome, green chemistry, organic synthesis, drug discovery

\section{INTRODUCTION}

The gut microbiota has proven to be an important source of bioactive metabolites (McNeil, 1984; De Vadder et al., 2014; Vernocchi et al., 2016; Postler and Ghosh, 2017), which are often able to interact with host receptors thanks to their structural similarity with endogenous signal molecules, such as those belonging to the endocannabinoidome (Iannotti and Di Marzo, 2021). This host signaling system includes hundreds of endocannabinoid-like long chain fatty acid-derived amides and esters, which signal at G-protein-coupled receptors (including the cannabinoid receptors), ligand-activated ion channels and peroxisome proliferator-activated receptors (PPARs) (Di Marzo, 2018). Gut microbiota metabolites can therefore act as highly specific modulators of important host functions and are very often well tolerated because biosynthesized by bacteria that live in symbiosis with the host. These aspects make bacterial endocannabinoidome-mimic molecules very promising candidates for the development of new drugs (Saha et al., 2016; Iannotti and Di Marzo, 2021).

In 2015, the discovery and structural identification of commendamide (Cohen et al., 2015) among the gut microbiota-derived metabolites aroused considerable interest due to its structure that is very similar to long-chain $\mathrm{N}$-acyl-amino acids [such as $\mathrm{N}$-oleoyl-glycine (Donvito et al., 2018)], which in the host signal through GPCRs (Cohen et al., 2017) and PPAR $\alpha$ (Donvito et al., 2018). In a very inspiring study (Cohen et al., 2015), Cohen et al. showed that commendamide was indeed able to interact with GPCRs by acting as an agonist of the GPCR G2A/132 receptor, implicated in autoimmunity and atherosclerosis. These interesting structural properties, its biogenic origin and bioactivity (Cohen et al., 2015; Lynch et al., 2017; Lynch et al., 2019; Piscotta et al., 2021), but also the presence of an $\mathrm{N}$-(3-hydroxyacyl)amino acid scaffold, which is a structural motif found in many other interesting bioactive products (Morishita et al., 1997; Nemoto et al., 1998; Fuqua and Greenberg, 2002; Grandclément et al., 2016; Lynch et al., 2019), make of commendamide, a metabolite at the cross-road of gut microbiota and host signaling, an exceptionally attractive target for chemical synthesis. 


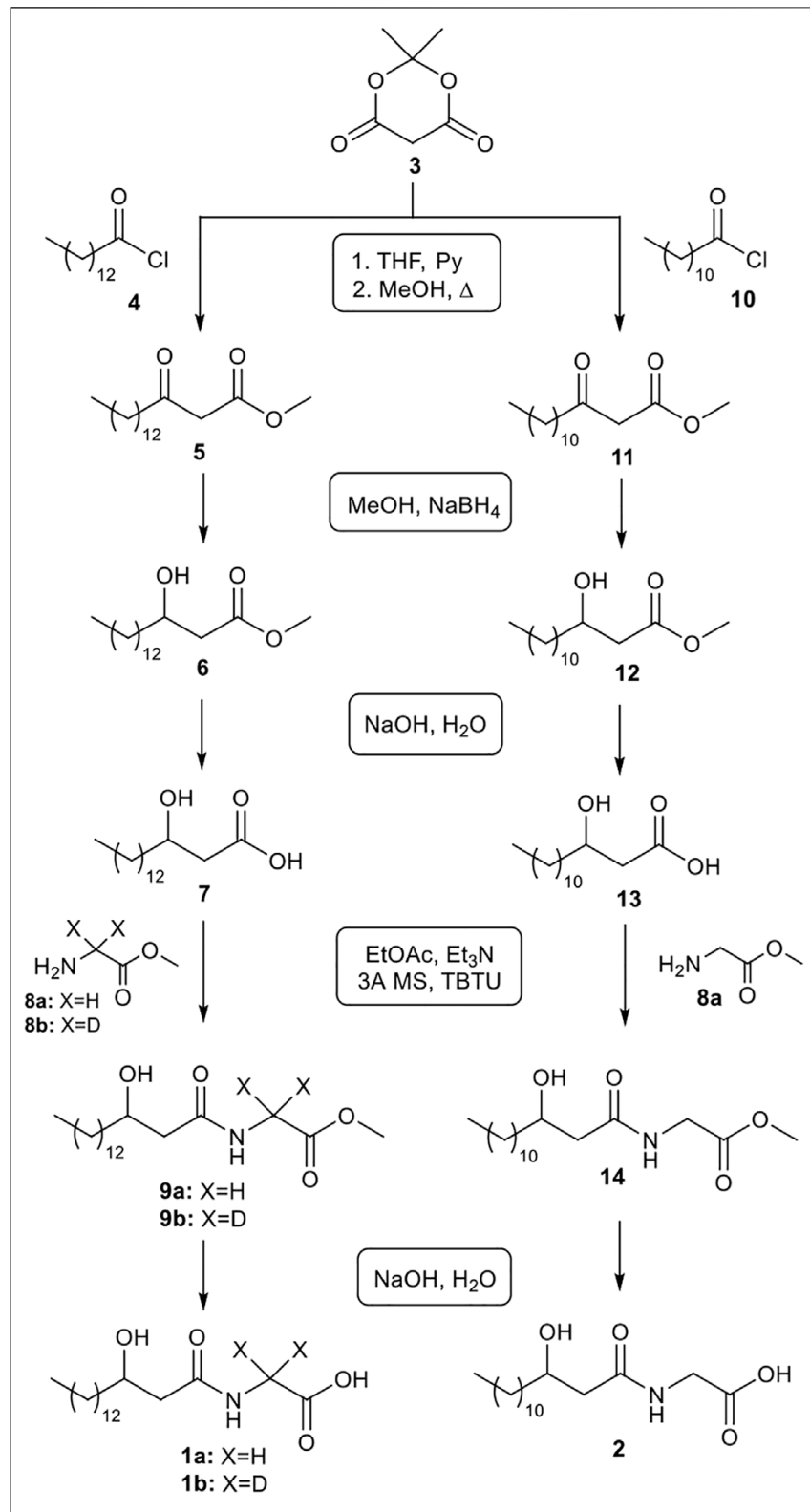

FIGURE 1 | Syntheses of commendamide 1a, deuterated commendamide $\mathbf{1 b}$ and metabolite $\mathbf{2}$.

Organic synthesis represents a powerful tool to conclusively confirm NMR and MS-based structure elucidation, and to produce greater amounts of the product, to be tested in vitro and in vivo (Nicolaou, 2014). Therefore, the elaboration of simple and effective synthetic protocols is very important; in addition, the development of versatile and general methodologies, which can also be used for the synthesis of the products in deuterated form (necessary for the development of LC-MS quantitative analysis methods) or to introduce structural modifications to the initial target molecule (for SAR studies) is highly desirable.

In the last decades, green chemistry (Horváth and Anastas, 2007; Li and Trost, 2008) has given impetus to a new generation of chemical syntheses through the creation of innovative reaction methodologies that can maximize the desired products and minimize waste, but also by identifying new synthetic sequences and equipments that can simplify the experimental procedures and replace old and often unsustainable protocols. These green syntheses, by employing more eco-friendly reaction conditions, represent a powerful tool in modern drug discovery programs.

Here, an easy and versatile methodology for the synthesis of the commendamide 1a is reported. This synthetic sequence (Figure 1) is characterized by the use of simple workups, readily available reagents, no halogenated solvent (for reaction, workup and purification) and minimal volumes of organic solvents. Furthermore, the high yields observed in many reaction steps often rendered unnecessary the use of column chromatography for the purification of synthetic intermediates. The same synthetic sequence was also successfully applied to the synthesis of deuterated commendamide $\mathbf{1 b}$ and another minor commendamide-like metabolite $\mathbf{2}$, with a poorly studied bioactivity, thus demonstrating the generality of the novel synthetic route presented here.

\section{METHODS}

\section{General}

All reagents and solvents were purchased from MerckSigmaAldrich and used as received. Reactions were monitored by thin layer chromatography (TLC) on Merck silica gel plates $(0.25 \mathrm{~mm})$ and visualized by UV light at $254 \mathrm{~nm}$ and cerium sulfate reagent. ${ }^{1} \mathrm{H}$ NMR and ${ }^{13} \mathrm{C}$ NMR spectra were recorded on a Bruker Avance-400 and on a Bruker DRX 600 equipped with an inverse TCI CryoProbe at room temperature in $\mathrm{CDCl}_{3}$ or $\mathrm{CD}_{3} \mathrm{OD}$. Chemical shifts are reported in ppm, multiplicities are indicated by s (singlet), d (doublet), $\mathrm{t}$ (triplet), $\mathrm{q}$ (quartet), $\mathrm{m}$ (multiplet) and br (broad). Coupling constants (J) are reported in $\mathrm{Hz}$. Yields are given for isolated products showing one spot on a TLC plate and no impurities detectable in the NMR spectrum.

\section{Synthetic Procedures and Characterization of Products}

Methyl 3-oxohexadecanoate (5): Pyridine (2 eq, $2.0 \mathrm{mmol}$ ) was added to a solution of Meldrum's acid (3; $1 \mathrm{eq}, 1.0 \mathrm{mmol})$ in THF $(0.7 \mathrm{ml})$ at room-temperature. The reaction was cooled at $0^{\circ} \mathrm{C}$ and myristoyl chloride $(4,1.2 \mathrm{eq}, 1.2 \mathrm{mmol})$ was portion-wise added to the solution. The reaction was warmed to $\mathrm{rt}$ and stirred overnight. After adding $1 \mathrm{~N} \mathrm{HCl}_{\mathrm{aq}}$ to $\mathrm{pH} 2$, the phases were separated and the $\mathrm{H}_{2} \mathrm{O}$ phase was extracted with EtOAc $(3 \times$ $2 \mathrm{ml}$ ). The combined organic layers were dried over $\mathrm{Na}_{2} \mathrm{SO}_{4}$. After evaporation of the solvent, the crude product was dissolved in $\mathrm{MeOH}(5 \mathrm{ml})$ and the reaction solution was mildly refluxed for $3 \mathrm{~h}$ by using a waterless air condenser (Asynt CondenSyn). After cooling to room temperature, the solvent was removed by reduced pressure and the crude product $\mathbf{5}$ was used directly without any further purification.

Methyl 3-hydroxyhexadecanoate (6): A solution of the product 5 in $\mathrm{MeOH}(1 \mathrm{ml})$ was prepared in a vial. The reaction was cooled 
at $0^{\circ} \mathrm{C}$ and $\mathrm{NaBH}_{4}$ (1 eq, $1.0 \mathrm{mmol}$ ) was added slowly; the reaction was stirred at $0^{\circ} \mathrm{C}$ for $30 \mathrm{~min}$ and, after adding $1 \mathrm{~N} \mathrm{HCl}_{\mathrm{aq}}$ to $\mathrm{pH} 7$, the reaction was warmed to $\mathrm{rt} . \mathrm{H}_{2} \mathrm{O}(2 \mathrm{ml})$ and EtOAc $(2 \mathrm{ml})$ were added to the reaction mixture, the phases were separated and the $\mathrm{H}_{2} \mathrm{O}$ phase was extracted with EtOAc $(2 \times 2 \mathrm{ml})$. The combined organic layers were dried over $\mathrm{Na}_{2} \mathrm{SO}_{4}$. After evaporation of the solvent, the crude product was purified by silica gel chromatography using a light petroleum ether/EtOAc 6/1 to give the product $6(0.9 \mathrm{mmol}, 90 \%$ yield from 3$)$. The spectroscopic data of $\mathbf{6}$ matched the ones reported in the literature (Jakob et al., 1996). ${ }^{1} \mathrm{H}-\mathrm{NMR}\left(\mathrm{CDCl}_{3}\right) \delta 4.00(\mathrm{~m}$, $1 \mathrm{H}), 3.71(\mathrm{~s}, 3 \mathrm{H}), 2.51(\mathrm{dd}, \mathrm{J}=3 \mathrm{~Hz}, 16.4 \mathrm{~Hz}, 1 \mathrm{H}), 2.40(\mathrm{dd}, \mathrm{J}$ $=9.1 \mathrm{~Hz}, 16.4 \mathrm{~Hz}, 1 \mathrm{H}), 1.52-1.27(\mathrm{~m}, 24 \mathrm{H}), 0.87(\mathrm{t}, \mathrm{J}=6.8 \mathrm{~Hz}$, $3 \mathrm{H}) .{ }^{13} \mathrm{C}-\mathrm{NMR}\left(\mathrm{CDCl}_{3}\right) \delta 173.5,68.0,51.7,41.1,36.5,31.9,29.7$, $29.6,29.5,29.3,25.5,22.7,14.1$ (some signals were overlapped).

3-Hydroxyhexadecanoic acid (7): $1 \mathrm{~N} \mathrm{NaOH}_{\mathrm{aq}}$ (10 eq, $\left.2.5 \mathrm{mmol}\right)$ was added to a solution of $6(0.25 \mathrm{mmol})$ in THF $(0.1 \mathrm{ml})$ at $0^{\circ} \mathrm{C}$. The reaction was stirred at $0^{\circ} \mathrm{C}$ for $30 \mathrm{~min}$ and then $2 \mathrm{~h}$ at $\mathrm{rt}$. After adding $1 \mathrm{~N} \mathrm{HCl}$ to $\mathrm{pH} 2$, the phases were separated and the $\mathrm{H}_{2} \mathrm{O}$ phase was extracted with EtOAc $(3 \times 2 \mathrm{ml})$. The combined organic layers were dried over $\mathrm{Na}_{2} \mathrm{SO}_{4}$ and the solvent was removed by reduced pressure to afford $\beta$-hydroxy-acid 7 as a colorless solid ( $0.22 \mathrm{mmol}, 88 \%$ yield). The spectroscopic data of 7 matched the ones reported in the literature (Bourboula et al., 2019). ${ }^{1} \mathrm{H}-\mathrm{NMR}$ $\left(\mathrm{CDCl}_{3}\right) \delta 4.02(\mathrm{~m}, 1 \mathrm{H}), 2.58(\mathrm{dd}, \mathrm{J}=3.0,16.6 \mathrm{~Hz}, 1 \mathrm{H}), 2.47(\mathrm{dd}, \mathrm{J}=$ 9.0, $16.6 \mathrm{~Hz}, 1 \mathrm{H}), 1.57-1.25(\mathrm{~m}, 24 \mathrm{H}), 0.88(\mathrm{t}, \mathrm{J}=6.8 \mathrm{~Hz}, 3 \mathrm{H})$. ${ }^{13} \mathrm{C}-\mathrm{NMR}\left(\mathrm{CDCl}_{3}\right) \delta 176.0,68.0,40.7,36.5,31.9,29.7,29.6,29.57$, 29.54, 29.5, 29.3, 25.4, 22.7, 14.1 .

Methyl (3-hydroxyhexadecanoyl)glycinate (9a): The $\beta$ hydroxy-acid $7(0.22 \mathrm{mmol})$ was dissolved in EtOAc $(2 \mathrm{ml})$. $3 \AA \mathrm{MS}$ (400 mg), Et ${ }_{3} \mathrm{~N}$ ( $3 \mathrm{eq}, 0.66 \mathrm{mmol}$ ) and TBTU (1 eq, $0.22 \mathrm{mmol}$ ) were added and the reaction mixture was stirred at rt for $1 \mathrm{~h}$. Then 8a (Wang et al., 2009) (2.5 eq, $0.55 \mathrm{mmol}$ ) was added and the reaction was kept stirring overnight. The reaction mixture was diluted by adding $3 \mathrm{ml}$ of $\mathrm{H}_{2} \mathrm{O}$; the phases were separated and the $\mathrm{H}_{2} \mathrm{O}$ phase was extracted with EtOAc $(3 \times$ $2 \mathrm{ml}$ ). The collected organic layer was dried over $\mathrm{Na}_{2} \mathrm{SO}_{4}$ and concentrated. The residue was purified by flash chromatography using a light petroleum ether/ethyl acetate $7 / 3$ to give 9 a $(0.16$ mmol, $73 \%$ yield). The spectroscopic data of 9 a matched the ones reported in the literature (Nemoto et al., 1998). ${ }^{1} \mathrm{H}-\mathrm{NMR}\left(\mathrm{CDCl}_{3}\right)$ $\delta 6.50(\mathrm{bs}, \mathrm{NH}, 1 \mathrm{H}), 4.07(\mathrm{dd}, \mathrm{J}=5.4,13.1 \mathrm{~Hz}, 1 \mathrm{H}), 4.03(\mathrm{dd}, \mathrm{J}=$ 5.3, $13.1 \mathrm{~Hz}, 1 \mathrm{H}), 4.02(\mathrm{~m}, 1 \mathrm{H}), 3.78$ (s, 3H), 2.84 (bs, OH, $1 \mathrm{H})$, $2.46(\mathrm{dd}, \mathrm{J}=2.5,15.1 \mathrm{~Hz}, 1 \mathrm{H}), 2.35(\mathrm{dd}, \mathrm{J}=9.1,15.1 \mathrm{~Hz}, 1 \mathrm{H}), 1.58-$ $1.27(\mathrm{~m}, 24 \mathrm{H}), 0.90(\mathrm{t}, \mathrm{J}=6.8 \mathrm{~Hz}, 3 \mathrm{H}) .{ }^{13} \mathrm{C}-\mathrm{NMR}\left(\mathrm{CDCl}_{3}\right) \delta 172.9$, $170.5,68.8,52.5,42.7,41.2,36.8,31.9,29.7,29.65,29.58,29.56$, 29.5, 29.3, 25.5, 22.7, 14.1 .

Methyl (3-hydroxyhexadecanoyl)glycinate- $d_{2}$ (9b) was synthesized according to the same protocol as described for 9a, by using $\mathbf{8 b}$ (Wang et al., 2009) instead of $\mathbf{8 a}$, with $75 \%$ yield. ${ }^{1} \mathrm{H}-\mathrm{NMR}\left(\mathrm{CDCl}_{3}\right) \delta 6.43$ (bs, NH, $\left.1 \mathrm{H}\right), 4.02(\mathrm{~m}, 1 \mathrm{H}), 3.78(\mathrm{~s}, 3 \mathrm{H})$, 2.84 (bs, OH, 1H), 2.46 (dd, J = 2.5, $15.1 \mathrm{~Hz}, 1 \mathrm{H}), 2.34$ (dd, J = 9.1, $15.1 \mathrm{~Hz}, 1 \mathrm{H}), 1.58-1.27(\mathrm{~m}, 24 \mathrm{H}), 0.90(\mathrm{t}, \mathrm{J}=6.8 \mathrm{~Hz}, 3 \mathrm{H}) .{ }^{13} \mathrm{C}-\mathrm{NMR}$ $\left(\mathrm{CDCl}_{3}\right) \delta 172.8,170.5,68.7,52.5,42.7,36.9,31.9,29.7,29.66$, 29.65, 29.58, 29.5, 29.3, 25.5, 22.7, 14.1 .

Commendamide or N-(3-hydroxypalmitoyl)-glycine (1a): $1 \mathrm{~N}$ $\mathrm{NaOH}_{\mathrm{aq}}$ (10 eq, $\left.1.3 \mathrm{mmol}\right)$ was added to a solution of 9a
$(0.13 \mathrm{mmol})$ in THF $(0.1 \mathrm{ml})$ at $0^{\circ} \mathrm{C}$. The reaction was stirred at $0^{\circ} \mathrm{C}$ for $30 \mathrm{~min}$ and then $3 \mathrm{~h}$ at rt. After adding $1 \mathrm{~N} \mathrm{HCl}$ to $\mathrm{pH} 2$, the formation of a solid was observed. The solid product was collected by filtration and washed with $\mathrm{H}_{2} \mathrm{O}(2 \times 1 \mathrm{ml})$ and then Etp/EtOAc $8 / 2(3 \times 1 \mathrm{ml})$ to give 1a as a colourless solid $(90 \%$ yield). Spectral data are consistent with a previous literature report (Cohen et al., 2015). ${ }^{1} \mathrm{H}-\mathrm{NMR}\left(\mathrm{CD}_{3} \mathrm{OD}\right) \delta 3.99$ (m, $1 \mathrm{H}), 3.93(\mathrm{ABq}, \mathrm{J}=17.8 \mathrm{~Hz}, 2 \mathrm{H}), 2.41(\mathrm{dd}, \mathrm{J}=5.0,14.3 \mathrm{~Hz}$, $1 \mathrm{H}), 2.37(\mathrm{dd}, \mathrm{J}=7.7,14.3 \mathrm{~Hz}, 1 \mathrm{H}), 1.52-1.31(\mathrm{~m}, 24 \mathrm{H}), 0.92(\mathrm{t}, \mathrm{J}=$ $6.8 \mathrm{~Hz}, 3 \mathrm{H}) .{ }^{13} \mathrm{C}-\mathrm{NMR}\left(\mathrm{CDCl}_{3}\right) \delta 173.3,171.7,68.3,43.2,40.4$, 36.7, 31.7, 29.4, 29.3, 29.2, 29.1, 25.2, 22.3, 13.0.

Commendamide- $d_{2}$ or $N$-(3-hydroxypalmitoyl)-glycine- $d_{2}(\mathbf{1 b})$ was synthesized based on to the same protocol as described for $\mathbf{1 a}$, by using $\mathbf{9 b}$ instead of $\mathbf{9 a}$, with $92 \%$ yield. ${ }^{1} \mathrm{H}-\mathrm{NMR}\left(\mathrm{CD}_{3} \mathrm{OD}\right) \delta$ $3.99(\mathrm{~m}, 1 \mathrm{H}), 2.41(\mathrm{dd}, \mathrm{J}=5.0,14.3 \mathrm{~Hz}, 1 \mathrm{H}), 2.37(\mathrm{dd}, \mathrm{J}=7.7,14.3$ $\mathrm{Hz}, 1 \mathrm{H}), 1.53-1.31(\mathrm{~m}, 24 \mathrm{H}), 0.92(\mathrm{t}, \mathrm{J}=6.8 \mathrm{~Hz}, 3 \mathrm{H}) .{ }^{13} \mathrm{C}-\mathrm{NMR}$ $\left(\mathrm{CDCl}_{3}\right) \delta 173.3,171.7,68.3,43.2,36.7,31.7,29.4,29.3,29.2,29.1$, 25.2, 22.3, 13.0.

Methyl 3-oxotetradecanoate (11): Pyridine (2 eq, $2.0 \mathrm{mmol}$ ) was added to a solution of Meldrum's acid (3; $1 \mathrm{eq}, 1.0 \mathrm{mmol})$ in THF $(0.7 \mathrm{ml})$ at room-temperature. The reaction was cooled at $0^{\circ} \mathrm{C}$ and lauroyl chloride (10, $1.2 \mathrm{eq}, 1.2 \mathrm{mmol}$ ) was portion-wise added to the solution. The reaction was warmed to $\mathrm{rt}$ and stirred overnight. After adding $1 \mathrm{~N} \mathrm{HCl}_{\mathrm{aq}}$ to $\mathrm{pH} 2$, the phases were separated and the $\mathrm{H}_{2} \mathrm{O}$ phase was extracted with EtOAc $(3 \times$ $2 \mathrm{ml}$ ). The combined organic layers were dried over $\mathrm{Na}_{2} \mathrm{SO}_{4}$. After evaporation of the solvent, the crude product was dissolved in $\mathrm{MeOH}(5 \mathrm{ml})$ and the reaction solution was mildly refluxed for $3 \mathrm{~h}$ by using a waterless air condenser (Asynt CondenSyn). After cooling to room temperature, the solvent was removed by reduced pressure and the crude product $\mathbf{1 1}$ was used directly without any further purification.

Methyl 3-hydroxytetradecanoate (12): A solution of the crude product 11 in $\mathrm{MeOH}(1 \mathrm{ml})$ was prepared in a vial. The reaction was cooled at $0^{\circ} \mathrm{C}$ and $\mathrm{NaBH}_{4}(1 \mathrm{eq}, 1.0 \mathrm{mmol})$ was added slowly; the reaction was stirred at $0^{\circ} \mathrm{C}$ for $30 \mathrm{~min}$ and, after adding $1 \mathrm{~N}$ $\mathrm{HCl}_{\mathrm{aq}}$ to $\mathrm{pH} \mathrm{7}$, the reaction was warmed to $\mathrm{rt} . \mathrm{H}_{2} \mathrm{O}(2 \mathrm{ml})$ and EtOAc $(2 \mathrm{ml})$ were added to the reaction mixture, the phases were separated and the $\mathrm{H}_{2} \mathrm{O}$ phase was extracted with EtOAc $(2 \times$ $2 \mathrm{ml}$ ). The combined organic layers were dried over $\mathrm{Na}_{2} \mathrm{SO}_{4}$. After evaporation of the solvent, the crude was purified by silica gel chromatography using a light petroleum ether/EtOAc 6/1 to give the product $12(0.75 \mathrm{mmol}, 75 \%$ yield from 3$)$. The spectroscopic data of $\mathbf{1 2}$ matched the ones reported in the literature (Hon et al., 2007). ${ }^{1} \mathrm{H}-\mathrm{NMR}\left(\mathrm{CDCl}_{3}\right) \delta 4.02(\mathrm{~m}$, $1 \mathrm{H}), 3.73$ (s, 3H), 2.53 (dd, J = $3 \mathrm{~Hz}, 16.4 \mathrm{~Hz}, 1 \mathrm{H}), 2.43$ (dd, J $=9.1 \mathrm{~Hz}, 16.4 \mathrm{~Hz}, 1 \mathrm{H}), 1.57-1.29(\mathrm{~m}, 20 \mathrm{H}), 0.90(\mathrm{t}, \mathrm{J}=6.8 \mathrm{~Hz}$, $3 \mathrm{H}) .{ }^{13} \mathrm{C}-\mathrm{NMR}\left(\mathrm{CDCl}_{3}\right) \delta 173.5,68.1,51.7,41.1,36.5,31.9,29.7$, 29.6, 29.5, 29.4, 29.3, 25.5, 22.7, 14.1 .

3-Hydroxytetradecanoic acid (13): $1 \mathrm{~N} \mathrm{NaOH}_{\mathrm{aq}}$ (10 eq, $7.5 \mathrm{mmol})$ was added to a solution of $12(0.75 \mathrm{mmol})$ in THF $(0.1 \mathrm{ml})$ at $0^{\circ} \mathrm{C}$. The reaction was stirred at $0^{\circ} \mathrm{C}$ for $30 \mathrm{~min}$ and then $2 \mathrm{~h}$ at $\mathrm{rt}$. After adding $1 \mathrm{~N} \mathrm{HCl}$ to $\mathrm{pH} 2$, the phases were separated and the $\mathrm{H}_{2} \mathrm{O}$ phase was extracted with EtOAc $(3 \times$ $2 \mathrm{ml}$ ). The combined organic layers were dried over $\mathrm{Na}_{2} \mathrm{SO}_{4}$ and the solvent was removed by reduced pressure to afford $\beta$ hydroxy-acid 13 as a colorless solid (0.67 mmol, $89 \%$ yield). 
The spectroscopic data of $\mathbf{1 3}$ matched the ones reported in the literature (Fukuchi et al., 1992). ${ }^{1} \mathrm{H}-\mathrm{NMR}\left(\mathrm{CDCl}_{3}\right) \delta 4.06(\mathrm{~m}, 1 \mathrm{H})$, $2.61(\mathrm{dd}, \mathrm{J}=3.1,16.6 \mathrm{~Hz}, 1 \mathrm{H}), 2.51(\mathrm{dd}, \mathrm{J}=8.8,16.6 \mathrm{~Hz}, 1 \mathrm{H}), 1.58-$ $1.27(\mathrm{~m}, 20 \mathrm{H}), 0.91(\mathrm{t}, \mathrm{J}=6.8 \mathrm{~Hz}, 3 \mathrm{H}) .{ }^{13} \mathrm{C}-\mathrm{NMR}\left(\mathrm{CDCl}_{3}\right) \delta 176.0$, $68.0,40.7,36.5,31.9,29.7,29.6,29.5$ (some signals were overlapped), 29.3, 25.4, 22.7, 14.1 .

Methyl (3-hydroxytetradecanoyl)glycinate (14): The $\beta$ hydroxy-acid $13(0.67 \mathrm{mmol})$ was dissolved in EtOAc $(6 \mathrm{ml})$. $3 \mathrm{~A} \mathrm{MS} \mathrm{(1} \mathrm{g),} \mathrm{Et}_{3} \mathrm{~N}$ (3 eq, $2.0 \mathrm{mmol}$ ) and TBTU (1 eq, $0.67 \mathrm{mmol}$ ) were added and the reaction was stirred at $\mathrm{rt}$ for $1 \mathrm{~h}$. Then $\mathbf{8 a}$ (Wang et al., 2009) (2.5 eq, $1.7 \mathrm{mmol}$ ) was added and the reaction was kept stirring overnight. The reaction mixture was diluted by adding $6 \mathrm{ml}$ of $\mathrm{H}_{2} \mathrm{O}$; the phases were separated and the $\mathrm{H}_{2} \mathrm{O}$ phase was extracted with EtOAc $(3 \times 4 \mathrm{ml})$. The collected organic layer was dried over $\mathrm{Na}_{2} \mathrm{SO}_{4}$ and concentrated. The residue was purified by flash chromatography using a light petroleum ether/ ethyl acetate $7 / 3$ to give 14 ( $0.47 \mathrm{mmol}, 70 \%$ yield). ${ }^{1} \mathrm{H}-\mathrm{NMR}$ $\left(\mathrm{CDCl}_{3}\right) \delta 6.40(\mathrm{bs}, \mathrm{NH}, 1 \mathrm{H}), 4.11(\mathrm{dd}, \mathrm{J}=5.4,18.3 \mathrm{~Hz}, 1 \mathrm{H}), 4.05$ (dd, J = 5.4, $18.3 \mathrm{~Hz}, 1 \mathrm{H}), 4.02(\mathrm{~m}, 1 \mathrm{H}), 3.79$ (s, 3H), 2.88 (bs, OH, $1 \mathrm{H}), 2.46(\mathrm{dd}, \mathrm{J}=2.6,15.1 \mathrm{~Hz}, 1 \mathrm{H}), 2.34(\mathrm{dd}, \mathrm{J}=9.1,15.1 \mathrm{~Hz}, 1 \mathrm{H})$, 1.58-1.27 (m, 20H), $0.90(\mathrm{t}, \mathrm{J}=6.5 \mathrm{~Hz}, 3 \mathrm{H}) .{ }^{13} \mathrm{C}-\mathrm{NMR}\left(\mathrm{CDCl}_{3}\right) \delta$ $172.7,170.5,68.7,52.5,42.7,41.1,36.8,31.9,29.65,29.63,29.58$, 29.5, 29.3, 25.5, 22.7, 14.1 .

3-Hydroxytetradecanoyl-glycine (2): $1 \mathrm{~N}$ NaOHaq (10 eq, $4.7 \mathrm{mmol})$ was added to a solution of $14(0.47 \mathrm{mmol})$ in THF $(0.1 \mathrm{ml})$ at $0^{\circ} \mathrm{C}$. The reaction was stirred at $0^{\circ} \mathrm{C}$ for $30 \mathrm{~min}$ and then $3 \mathrm{~h}$ at $\mathrm{rt}$. After adding $1 \mathrm{~N} \mathrm{HCl}$ to $\mathrm{pH} 2$, the formation of a solid was observed. The solid product was collected by filtration and washed with $\mathrm{H}_{2} \mathrm{O}(2 \times 2 \mathrm{ml})$ and then Etp/EtOAc 8/2 $(3 \times$ $2 \mathrm{ml})$ to give 2 as a colourless solid with $89 \%$ yield $(0.42 \mathrm{mmol})$. This spectral data is consistent with a previous literature report (Morishita et al., 1997; Cohen et al., 2015). ${ }^{1} \mathrm{H}-\mathrm{NMR}\left(\mathrm{CD}_{3} \mathrm{OD}\right) \delta$ $3.99(\mathrm{~m}, 1 \mathrm{H}), 3.94(\mathrm{ABq}, \mathrm{J}=17.8 \mathrm{~Hz}, 2 \mathrm{H}), 2.41(\mathrm{dd}, \mathrm{J}=5.0,14.3$ $\mathrm{Hz}, 1 \mathrm{H}), 2.37(\mathrm{dd}, \mathrm{J}=7.7,14.3 \mathrm{~Hz}, 1 \mathrm{H}), 1.53-1.31(\mathrm{~m}, 20 \mathrm{H}), 0.92$ $(\mathrm{t}, \mathrm{J}=6.8 \mathrm{~Hz}, 3 \mathrm{H}) .{ }^{13} \mathrm{C}-\mathrm{NMR}\left(\mathrm{CDCl}_{3}\right) \delta 173.3,171.7,68.3,43.2$, $40.3,36.7,31.7,29.4,29.35,29.34,29.3$ (some signals were overlapped), 29.1, 25.2, 22.3, 13.0 .

\section{RESULTS AND DISCUSSION}

As delineated in Figure 1, 3-hydroxypalmitic acid 7 was the key intermediate for the production of commendamide 1a. Several methods for the synthesis of 3-hydroxy carboxylic acids are reported in the literature and they mainly use the Reformatsky reaction (Gawrorisk, 1984) or the reduction of $\beta$-ketoesters obtained by acylation of Meldrum's acid (Oikawa et al., 1978; Hodgkinson et al., 2011; Brinkerhoff et al., 2014; Brosge et al., 2021) or $\gamma$-alkylation of acetoacetate (Smith et al., 2009). Here, we started from the reaction between the commercially available Meldrum's acid 3 and myristoyl chloride 4. Unlike the protocols reported in literature, this $\mathrm{C}$-acylation was carried out in a minimal volume of THF (workup with EtOAc) instead of classical $\mathrm{CH}_{2} \mathrm{Cl}_{2}$, without any reduction in the efficiency of the reaction. Because the acyl Meldrum's acid derivatives are decomposed by column chromatography, the crude product was used without any further purification and directly converted to methyl 3-oxohexadecanoate 5 by alcoholysis with methanol. This reaction was performed at $72-75^{\circ} \mathrm{C}$, by classical heating $(3 \mathrm{~h})$ in the presence of a waterless air condenser (Asynt CondenSyn $)^{1}$, an eco-friendly equipment that reduces water waste. The crude $\beta$-ketoester 5 was swiftly converted into $\beta$ hydroxy-ester 6 by reduction with $\mathrm{NaBH}_{4}$ in $\mathrm{MeOH}\left(30 \mathrm{~min} / 0^{\circ} \mathrm{C}\right)$ and the product 6 was easily isolated by column chromatography (90\% yield from 3, after 3 reaction steps). Saponification of the methyl ester group with $\mathrm{NaOH}$ in water gave the corresponding $\beta$-hydroxy-acid 7 as a colorless solid in $88 \%$ yield. In order to increase the solubility of product $\mathbf{6}$ and improve the efficiency of the reaction, a small volume $(100 \mu \mathrm{L})$ of THF was also added as co-solvent. TBTU-mediated coupling of 7 with glycine methyl ester hydrochloride 8a [prepared according to the literature (Wang et al., 2009)], in the presence of $\mathrm{Et}_{3} \mathrm{~N}$ and $3 \AA \mathrm{MS}$ provided the glycinate 9a with an interesting yield (73\%) after purification by flash chromatography. Finally, commendamide 1a was obtained as a colourless solid by saponification of the derivative 9a and, after crystallization, was collected by filtration (total yield $52 \%$ from 3 ).

The synthesis of commendamide was reported by Cohen in 2015 (Cohen et al., 2015). In this case the racemic product was prepared by a coupling reaction between 3-hydroxy-palmitic acid and glycine promoted by $\mathrm{PyBOP}$ and $\mathrm{Cl}-\mathrm{HOBt}$. Unfortunately, the article does not provide sufficient synthetic details and the final product was obtained in very small amount (less than $6 \%$ of yield).

The synthetic sequence from 3 to 1a was rather concise (6 steps) and all reactions gave the corresponding products with good yields, without formation of side-products. All reactions of this sequence were not very water-sensitive, so they did not need to be carried out under an inert atmosphere, nor did they require the use of anhydrous reagents, solvents, glassware, and equipments. Furthermore, most of the reactions were realized at room temperature, while low temperatures $\left(0^{\circ} \mathrm{C}\right)$ and high temperatures $\left(75^{\circ} \mathrm{C}\right)$ were used only in a few steps for very limited times. In addition, all workups were very simple and column chromatography was performed only for the purification of two synthetic intermediates, since the other products were used in crude form or after purification by crystallization and filtration, with a significant and beneficial reduction in the amount of solvent and energy needed for the separation and purification of intermediates. Finally, this synthetic sequence was readily scalable (up to $5 \mathrm{mmol}$ ) without substantial change in efficiency.

The same synthetic protocol was also applied to the synthesis of deuterated commendamide $\mathbf{1 b}$ (Figure 1); in this case, deuterated glycine methyl ester hydrochloride $\mathbf{8 b}$ [prepared according to the literature (Wang et al., 2009)], was used in the coupling reaction with 3-hydroxypalmitic acid 7. Deuterated commendamide $\mathbf{1 b}$ was synthesized with a total yield of $55 \%$ from 3 .

To further explore the synthetic value of this strategy, we extended it to the synthesis of another poorly studied gut-

${ }^{1}$ http://www.asynt.com/product/asyntcondensyn-air-condenser/ 

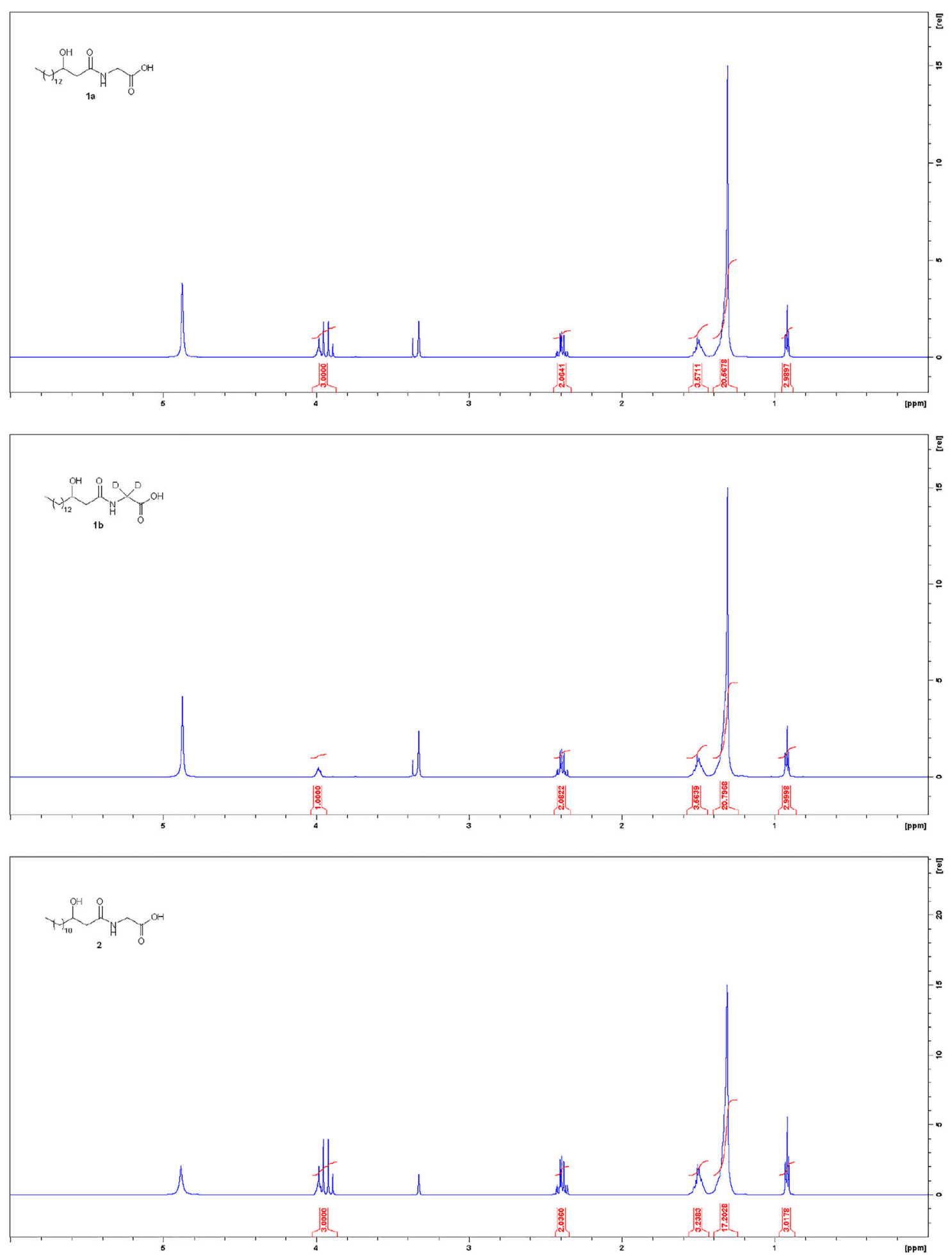

FIGURE $2 \mid{ }^{1} \mathrm{H}$ NMR spectra $\left(600 \mathrm{MHz}, \mathrm{CD}_{3} \mathrm{OD}\right)$ of synthetic products $\mathbf{1 a}, \mathbf{1 b}$ and $\mathbf{2}$.

microbiota metabolite, that is the commendamide analog 2 (Figure 1). In this case, C-acylation of the Meldrum's acid 3 was performed with lauroyl chloride 10, then the alcoholysis with
$\mathrm{MeOH}$, followed by reduction with $\mathrm{NaBH}_{4}$ and saponification gave $\beta$-hydroxy-myristic acid 13. Finally, TBTU-mediated coupling of 13 with glycine methyl ester hydrochloride $\mathbf{8 a}$ 
followed by saponification produced the derivative 2 with $42 \%$ overall yield from 3, which is higher than that reported in the literature by using a different synthetic protocol (Venkateswaran et al., 2016).

The possibility to apply the same synthetic sequence for the production of several products with a 3-hydroxyacyl glycine scaffold (highly pure $\mathbf{1 a}, \mathbf{1} \mathbf{b}$ and $\mathbf{2}$, Figure 2 ) confirmed the generality and versatility of the developed strategy.

\section{CONCLUSION}

In conclusion, a practical and "green" procedure for the synthesis of commendamide and its analogues was developed. This procedure involved a total of six steps to obtain highly pure $\mathrm{N}$-(3-hydroxyacyl) glycines (Figure 2) from the commercially available Meldrum's acid and acyl-chloride. Key advantages are that all reactions of this synthetic sequence gave the corresponding products with high yields, without formation of side-products, and only two column chromatographic purifications were needed with a beneficial reduction in the amount of solvent and energy needed for separation and purification; furthermore, all reactions were not very watersensitive, so they did not need to be carried out under an inert atmosphere, and they did not require the use of anhydrous reagents/solvents/glassware.

The possibility to apply the same synthetic sequence for the production of several products with a 3-hydroxyacyl glycine scaffold (1a, 1b and 2) confirmed the generality and versatility of the developed strategy. Given the simplicity and high efficiency of this synthetic sequence, the extension of this methodology toward the synthesis of other gut microbiota-derived commendamide-like metabolites (Cohen et al., 2017) for biological evaluation, in vitro and in vivo, are underway in our laboratory. Finally, the separation of the single enantiomers by chiral HPLC will allow to test their individual biological activities and evaluate any differences between the stereoisomers (in

\section{REFERENCES}

Bourboula, A., Limnios, D., Kokotou, M. G., Mountanea, O. G., and Kokotos, G. (2019). Enantioselective Organocatalysis-Based Synthesis of 3-Hydroxy Fatty Acids and Fatty $\gamma$-Lactones. Molecules 24, 2081. doi:10.3390/molecules 24112081

Brinkerhoff, R. C., Tarazona, H. F., de Oliveira, P. M., Flores, D. C., Montes D’Oca, C. D. R., Russowsky, D., et al. (2014). Synthesis of $\beta$-ketoesters from Renewable Resources and Meldrum's Acid. RSC Adv. 4, 49556-49559. doi:10.1039/ c4ra08986c

Brosge, F., Singh, P., Almqvist, F., and Bolm, C. (2021). Selected Applications of Meldrum's Acid - a Tutorial. Org. Biomol. Chem. 19, 5014-5027. doi:10.1039/ d1ob00395j

Cohen, L. J., Esterhazy, D., Kim, S.-H., Lemetre, C., Aguilar, R. R., Gordon, E. A., et al. (2017). Commensal Bacteria Make GPCR Ligands that Mimic Human Signalling Molecules. Nature 549, 48-53. doi:10.1038/nature23874

Cohen, L. J., Kang, H.-S., Chu, J., Huang, Y.-H., Gordon, E. A., Reddy, B. V. B., et al. (2015). Functional Metagenomic Discovery of Bacterial Effectors in the Human Microbiome and Isolation of Commendamide, a GPCR G2A/132 Agonist. Proc. Natl. Acad. Sci. USA 112, E4825-E4834. doi:10.1073/pnas.1508737112

De Vadder, F., Kovatcheva-Datchary, P., Goncalves, D., Vinera, J., Zitoun, C., Duchampt, A., et al. (2014). Microbiota-generated Metabolites Promote addition to the biological tests performed on the racemic products).

\section{DATA AVAILABILITY STATEMENT}

The original contributions presented in the study are included in the article, further inquiries can be directed to the corresponding author.

\section{AUTHOR CONTRIBUTIONS}

RV and VD designed research; RV and FT performed research; $\mathrm{VD}$ supervised the project and provided funding acquisition; RV wrote the original draft; VD reviewed and edited the manuscript. RV, FT, and VD discussed the results and commented on the manuscript. All authors read and approved the final manuscript.

\section{FUNDING}

FT was supported by a post-doctoral fellowship from the UMI MicroMeNu.

\section{ACKNOWLEDGMENTS}

The financial support from MUR PRIN 2017XC73BW_002_CUP B84I19002450001 and Unité Mixte Internationale (UMI) for Chemical and Biomolecular Research on the Microbiome and its impact on Metabolic Health and Nutrition (MicroMeNu), which is partly funded by the Sentinelle Nord project, supported by the Apogée (Canada First) programme from the Federal Tri-Agency of Canada, is acknowledged.

Metabolic Benefits via Gut-Brain Neural Circuits. Cell 156, 84-96. doi:10 1016/j.cell.2013.12.016

Di Marzo, V. (2018). New Approaches and Challenges to Targeting the Endocannabinoid System. Nat. Rev. Drug Discov. 17, 623-639. doi:10.1038/ nrd.2018.115

Donvito, G., Piscitelli, F., Muldoon, P., Jackson, A., Vitale, R. M., D’Aniello, E., et al. (2019). N-Oleoyl-glycine Reduces Nicotine Reward and Withdrawal in Mice. Neuropharmacology 148, 320-331. doi:10.1016/j.neuropharm.2018.03.020

Fukuchi, N., Isogai, A., Nakayama, J., Takayama, S., Yamashita, S., Suyama, K., et al. (1992). Isolation and Structural Elucidation of Syringostatins, Phytotoxins Produced by Pseudomonas syringae Pv. Syringae Lilac Isolate. J. Chem. Soc. Perkin Trans. 1, 875-880. doi:10.1039/P19920000875

Fuqua, C., and Greenberg, E. P. (2002). Listening in on Bacteria: Acyl-Homoserine Lactone Signalling. Nat. Rev. Mol. Cel Biol. 3, 685-695. doi:10.1038/nrm907

Gawrorisk, J. K. (1984). Tandem Reformatsky Reactions of 2-bromopropionates in the Presence of Chlorotrimethylsilane. Tetrahedron Lett. 25, 2605-2608. doi:10. 1016/S0040-4039(01)81242-9

Grandclément, C., Tannières, M., Moréra, S., Dessaux, Y., and Faure, D. (2016). Quorum quenching: Role in Nature and Applied Developments. FEMS Microbiol. Rev. 40, 86-116. doi:10.1093/femsre/fuv038

Hodgkinson, J. T., Galloway, W. R. J. D., Casoli, M., Keane, H., Su, X., Salmond, G. P. C., et al. (2011). Robust Routes for the Synthesis of N-Acylated-L-Homoserine 
Lactone (AHL) Quorum Sensing Molecules with High Levels of Enantiomeric Purity. Tetrahedron Lett. 52, 3291-3294. doi:10.1016/j.tetlet.2011.04.059

Hon, Y. S., Hsieh, C. H., and Chen, H. F. (2007). Dibromomethane as One-Carbon Source in Organic Synthesis: Formal Total Synthesis of $( \pm)$-Nephrosteranic Acid. Synth. Commun. 37, 1635-1651. doi:10.1080/00397910701263767

Horváth, I. T., and Anastas, P. T. (2007). Innovations and Green Chemistry. Chem. Rev. 107, 2169-2173. doi:10.1021/cr078380v

Iannotti, F. A., and Di Marzo, V. (2021). The Gut Microbiome, Endocannabinoids and Metabolic Disorders. J. Endocrinol. 248, R83-R97. doi:10.1530/JOE-20-0444

Jakob, B., Voss, G., and Gerlach, H. (1996). Synthesis of (S)- and (R)-3Hydroxyhexadecanoic Acid. Tetrahedron: Asymmetry 7, 3255-3262. doi:10. 1016/0957-4166(96)00426-0

Li, C.-J., and Trost, B. M. (2008). Green Chemistry for Chemical Synthesis. Proc. Natl. Acad. Sci. 105, 13197-13202. doi:10.1073/pnas.0804348105

Lynch, A., Crowley, E., Casey, E., Cano, R., Shanahan, R., McGlacken, G., et al. (2017). The Bacteroidales Produce an N-Acylated Derivative of glycine with Both Cholesterol-Solubilising and Hemolytic Activity. Sci. Rep. 7, 13270-13280. doi:10.1038/s41598-017-13774-6

Lynch, A., Tammireddy, S. R., Doherty, M. K., Whitfield, P. D., and Clarke, D. J. (2019). The glycine Lipids of Bacteroides Thetaiotaomicron Are Important for Fitness during Growth In Vivo and In Vitro. Appl. Environ. Microbiol. 85, e02157. doi:10.1128/AEM.02157-18

McNeil, N. I. (1984). The Contribution of the Large Intestine to Energy Supplies in Man. Am. J. Clin. Nutr. 39, 338-342. doi:10.1093/ajcn/39.2.338

Morishita, T., Sato, A., Hisamoto, M., Oda, T., Matsuda, K., Ishii, A., et al. (1997). N-type Calcium Channel Blockers from a marine Bacterium, Cytophaga Sp. SANK 71996. J. Antibiot. 50, 457-468. doi:10.7164/antibiotics.50.457

Nemoto, T., Ojika, M., Takahata, Y., Andoh, T., and Sakagami, Y. (1998). Structures of Topostins, DNA Topoisomerase I Inhibitors of Bacterial Origin. Tetrahedron 54, 2683-2690. doi:10.1016/S0040-4020(98)83004-4

Nicolaou, K. C. (2014). Organic Synthesis: the Art and Science of Replicating the Molecules of Living Nature and Creating Others like Them in the Laboratory. Proc. R. Soc. A. 470, 20130690. doi:10.1098/rspa.2013.0690

Oikawa, Y., Sugano, K., and Yonemitsu, O. (1978). Meldrum's Acid in Organic Synthesis. 2. A General and Versatile Synthesis of .beta.-keto Esters. J. Org. Chem. 43, 2087-2088. doi:10.1021/jo00404a066

Piscotta, F. J., Whitfield, S. T., Nakashige, T. G., Estrela, A. B., Ali, T., and Brady, S. F. (2021). Multiplexed Functional Metagenomic Analysis of the Infant
Microbiome Identifies Effectors of NF-Kb, Autophagy, and Cellular Redox State. Cel Rep. 36, 109746. doi:10.1016/j.celrep.2021.109746

Postler, T. S., and Ghosh, S. (2017). Understanding the Holobiont: How Microbial Metabolites Affect Human Health and Shape the Immune System. Cel Metab. 26, 110-130. doi:10.1016/j.cmet.2017.05.008

Saha, S., Rajpal, D. K., and Brown, J. R. (2016). Human Microbial Metabolites as a Source of New Drugs. Drug Discov. Today 21, 692-698. doi:10.1016/j.drudis. 2016.02.009

Smith, J. W., Romo, D., Ma, G., and Zancanella, M. (2009). Beta-lactone Compounds. US 2009/0124681 A1.

Venkateswaran, A., Raman, B., Swanson, P., and Lewer, P. (2016). Heterologous Expression of glycine N-Acyltransferase Proteins. WO 2016/049487 A1. Indianapolis IN: WIPO.

Vernocchi, P., Del Chierico, F., and Putignani, L. (2016). Gut Microbiota Profiling: Metabolomics Based Approach to Unravel Compounds Affecting Human Health. Front. Microbiol. 7, 1-21. doi:10.3389/fmicb. 2016.01144

Wang, M., Opare, P., and Boddy, C. N. (2009). Polyketide Synthase Thioesterases Catalyze Rapid Hydrolysis of Peptidyl Thioesters. Bioorg. Med. Chem. Lett. 19, 1413-1415. doi:10.1016/j.bmcl.2009.01.040

Conflict of Interest: The authors declare that the research was conducted in the absence of any commercial or financial relationships that could be construed as a potential conflict of interest.

Publisher's Note: All claims expressed in this article are solely those of the authors and do not necessarily represent those of their affiliated organizations, or those of the publisher, the editors and the reviewers. Any product that may be evaluated in this article, or claim that may be made by its manufacturer, is not guaranteed or endorsed by the publisher.

Copyright (C) 2022 Villano, Tinto and Di Marzo. This is an open-access article distributed under the terms of the Creative Commons Attribution License (CC BY). The use, distribution or reproduction in other forums is permitted, provided the original author(s) and the copyright owner(s) are credited and that the original publication in this journal is cited, in accordance with accepted academic practice. No use, distribution or reproduction is permitted which does not comply with these terms. 